\title{
Comparative fibrolytic activity of different microbial populations from rabbit caecum and bovine rumen
}

\author{
N Jehl 1, C Martin 2, P Nozière 2, T Gidenne 1, B Michalet-Doreau 2 \\ 1INRA, Station de Recherches Cunicoles, 31320 Castanet Tolosan ; INRA, SRNH, \\ Theix, 63122 St-Genès-Champanelle, France
}

As in the bovine rumen, plant cell walls are degraded in the rabbit caecum by enzymes produced by fibrolytic microbial flora. The caecal microflora contrasts from that of the rumen by absence of protozoa and predominance of Bacteroïdes species. In the rumen, solid-associated bacteria (SAB) represent the most important bacterial population (about $75 \%$ ) (Legay-Carmier and Bauchart, 1989, Br J Nutr, 61, 725-740), and differentiate from the liquid-associated bacteria (LAB) by both their chemical composition (Merry and Mc Allan, 1983, Br J Nutr, 50, 701-709) and their higher glycolytic activity (Martin et al, 1993, Curr Microbiol, 27, 223228). In the rabbit caecum, distribution and enzyme activity of the microbial population are not well known.

The aim of this study was to evaluate whether the separation between liquid and solidassociated caecal bacteria is opportune or not, and to compare the fibrolytic activity of rabbit caecal bacteria and ruminal bacteria

The experiment was conducted with rabbits fed ad libitum and cows restricted to $80 \%$ ad libitum, on fibre rich diets : $40 \%$ (NDF) for the two rabbit diets (diets 1 and 2 ) and $60 \%$ for the cow diet (diet 3 ). Caecal contents were collected at the end of the caecotrophy period (11 am) and ruminal content $23 \mathrm{~h}$ after feeding.
After sonication under anaerobic conditions, samples from SAB and LAB (diets 1 and 3) or whole bacteria (WB) (diet 2) were assessed for their celluloiytic (CMCase and avicelase) and hemicellulolytic (xylanase) specific activities (Williams and Strachan, 1984, Curr Microbiol, 10, 215-220).

Ruminal $L A B$ were not involved in plant cell wall polysaccharides degradation. In the rabbit caecum, the fibrolytic activity was similar in $S A B$ and $L A B$, but showed an important variability, suggesting a transitory or a random distribution between $S A B$ and $L A B$ population. In contrast, the fibrolytic activity of whole bacterial population (WB) had a variability similar to that registered for rumen $\mathrm{SAB}$. In addition, the great homogeneity of caecal digesta and its high DM level (20\%), contrasted with those of the rumen. Thus, the fractionation of caecal flora into free and adherent bacteria seemed not justified. Activity of the caecal WB was lower than ruminal SAB, but contamination of the enzymatic extract by endogenous proteins may induce an underestimation of the specific enzyme activity in the caecum. Nevertheless, the measurement of enzyme activity seems to be an interesting approach to study the rabbit microbial caecum ecosystem and its eventual modifications by the dietary conditions.

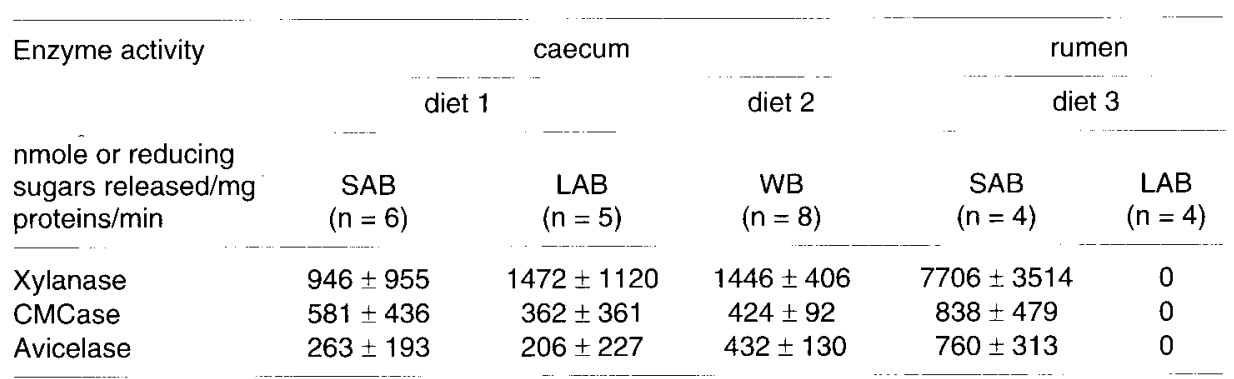

